\title{
Social media marketing influence on Boutique Hotel customers' purchase intention in Malaysia
}

\author{
Influência do marketing nas redes sociais na intenção de compra dos clientes de Hotéis Boutique na Malásia
}

\author{
Anshul Garg \\ School of Hospitality, Tourism \& Events, Faculty of Social Sciences and Leisure Management, \\ Taylor's University, Malaysia, anshul.garg@taylors.edu.my
}

Jeetesh Kumar

School of Hospitality, Tourism and Events, Centre for Research and Innovation in Tourism (CRiT), Faculty of Social Sciences and Leisure Management, Taylor's University, Malaysia, jeetesh.kumar@taylors.edu.my

Received: 26.02.2021; Revisions required: 03.04.2021; Accepted: 20.07.2021

\begin{abstract}
As of January 2020 , global social media users have exceeded 3.8 billion, accounting for $49 \%$ of the world's total population. Internet and social media have become an indispensable part of people's daily lives worldwide. However, most previous research only focuses on social media marketing in other businesses, and there is less research about the development of boutique hotel social media marketing. This study investigates the relationship between different social media marketing practices and customers' purchase intention in Malaysia's boutique hotels. The article also explores how to properly conduct social media marketing to increase the customer purchase intention of boutique hotels and promote the boutique hotels' development in Malaysia. The non-probability random sampling technique 309 response was collected from Malaysian social media users using an online survey. Findings of the research found out that factors including marketing activities and eWOM significantly impact customer purchase intention of the boutique hotels in Malaysia through the mediating variable perceived usefulness and the mediating variable perceived trust. The study offers implications for the development of social media marketing in boutique hotels.
\end{abstract}

Keywords: Boutique Hotel, social media marketing, purchase intention, malaysia, electronic word of mouth, perceived trust.

\section{Resumo}

Em janeiro de 2020, os utilizadores globais de redes sociais ultrapassaram 3,8 biliões, representando $49 \%$ da população total do mundo. A Internet e as redes sociais tornaram-se uma parte indispensável da vida diária das pessoas. No entanto, a maioria das pesquisas anteriores centra-se apenas no marketing nas redes sociais noutros tipos de empresas, e há poucas pesquisas sobre o desenvolvimento de marketing em redes sociais em hotéis boutique. Este estudo investiga a relação entre diferentes práticas de marketing em redes sociais e a intenção de compra dos clientes de hotéis boutique na Malásia. $O$ artigo também explora como conduzir adequadamente o marketing de redes sociais para aumentar a intenção de compra do cliente em e promover o desenvolvimento dos hotéis boutique na Malásia. A técnica de amostragem aleatória não probabilística com 309 respostas foi coletada de utilizadores de redes sociais da Malásia por meio de uma pesquisa online. Os resultados da investigação demonstram que fatores incluindo atividades de marketing e eWOM impactam significativamente na intenção de compra do cliente por meio da variável mediadora utilidade percebida e da variável mediadora confiança percebida. $O$ estudo oferece implicações para o desenvolvimento do marketing de redes sociais em hotéis boutique.

Palavras-chave: Hotel Boutique, marketing de redes sociais, Intenção de compra, Malásia, Boca a boca eletrónica, confiança percebida.

\section{Introduction}

Since the 1990s, the global Internet has entered commercial use and has expanded rapidly. As of January 2021, the estimated world demographics were 7.8 billion, and as of the 2020 year, Q3 estimates, the number of internet users worldwide had reached 4,929,926,187 (Internetworldstats, 2020). According to the data, the average penetration rate of internet users worldwide has gained $63.2 \%$. The Internet incorporates itself into a compelling information-sharing platform. People around the world can communicate through the internet and share resources conveniently and quickly. It has become a critical information infrastructure and the basic structure of various industries, promoting social progress and economic development. In the continuous changes of the Internet, social media has developed rapidly as an innovative product. According to the GlobalWeblndex report, ordinary people take time on social media for two hours and twenty-four minutes every day (Kemp, 2020). Mobile, digital, and social media are closely connected with people's lives worldwide and have become a requisite part of people's lives (Kemp, 2020). Social

media includes Facebook, Instagram, Twitter, and other forms of platforms, which migrate people's real-life social relationship networks to the Internet, and derives new social relationship networks (Alhabash \& Ma, 2017). Social media users have transformed from passive receivers of information to active creators of knowledge. The generation of marketing content is due to consumers' active discussions and content sharing on social media, stimulating and influencing consumers' purchase intention and purchase behaviour (Duffett, 2017). Many companies regard the rapid rise of social media as a good opportunity. They have begun to consider how to rely on social media platforms to establish intimate and friendly relationships with customers and deepen interaction and communication with customers (Arora, Bansal, Kandpal, Aswani, \& Dwivedi, 2019; Saura, 2020).

Entrepreneurs use social media mainly to market their products/services (Olanrewaju, Hossain, Whiteside, \& Mercieca, 2020). In the hotel marketing management process, managers have already apprehended the critical role of various social media. With the changes in the competitive environment 
and the rapid development of information technology, social media marketing plays a more significant role in developing the hospitality industry (Varkaris \& Neuhofer, 2017). Compared with other global sectors, the hospitality industry is expanding at an unprecedented rate. The hospitality industry is receiving better attention, and more and more customers are concerned about the quality of products than just quantity (UK Essays, 2017). The hospitality industry is a people-oriented service industry. In recent years, the Malaysian hospitality industry has achieved positive growth with the global hospitality industry's rapid development. Malaysia's tourism industry has become one of the national economy's essential pillars (Bernama, 2017). A large part of the hospitality industry's diversity is boutique hotels, leading to increased boutique hotels (Aggett, 2007). Unlike other hotels, boutique hotels are a unique accommodation experience, and their unique style and personalised high service level are highly emphasised. Due to the uniqueness of boutique hotels, their operation needs to meet higher and newer requirements. The development of boutique hotels is inseparable from social media, and social media marketing is one of the most potent instruments for boutique hotels to maximise marketing effectiveness.

Social media is having a substantial impact on consumers' purchase behaviour. Millennials are currently the most populous generation globally (Taha, Pencarelli, Škerháková, Fedorko, \& Košíková , 2021) and represent the highest-spending generation in 2020 - with a projected \$1.4 trillion (Kasasa, 2021). Generation $Y$ is the newcomer both in the workplace and visitors category. Generation $Y$ is the most significant tourism industry participant as they are now in the active phase of their birth cycle. The core of Generation $\mathrm{Y}$ is called millennials (Garg, 2020). The content posted on social media has become a source of inspiration for millennials. According to the study conducted by Payne (2019), $83 \%$ of millennials' hotel bookings will be affected by what they see on social media.

$73 \%$ of people also admit that they checked the hotel's social media homepage information before booking (Payne, 2019). It is also essential that one-third of people are unlikely to continue booking if the hotel does not have a social media homepage. Social media has a significant impact on most consumers' behaviour and purchasing decisions, and it has also become an indispensable marketing tool for the hospitality industry. Social media has changed how users communicate and use Internet-based sites to divide content between digital media and Internet users. (Abbas, Aman, Nurunnabi, \& Bano, 2019; Baccarella, Wagner, Kietzmann, \& McCarthy, 2018). In this era where data is the value (Saura, Ribeiro-Soriano \& Palacios-Marqués, 2021), hotel operators can more easily confirm consumers' preferences and consumption needs through data mining and analysis accurately grasp consumers' psychological needs (Berezan, Krishen, Agarwal, \& Kachroo, 2018). Undoubtedly, choosing good social media as a marketing instrument is crucial for developing the hospitality industry.
Many scholars have analysed online consumers' purchasing intention with the extensive development of social media marketing in various fields. However, most of these analyses study consumers' purchase intention at a macro level. There is very little research on the analysis of boutique hotel consumers' purchase intention, and there is not much research on the social media marketing of boutique hotels. Thus, the purpose of this study is to investigate how different social media marketing methods affect Malaysian boutique hotel customers' purchase intention and explore social media marketing strategies suitable for Malaysian boutique hotels. This study can provide suggestions for the future development of boutique hotels in Malaysia to implement social media marketing strategies better from a long-term perspective. This study will analyse consumer purchasing behaviour and propose marketing strategies in the context of the Internet era, not only for boutique hotels but also for the entire hotel industry and other industries. Moreover, this research strengthens the marketing theory and social media marketing theory from an academic perspective and enriches the research on boutique hotel consumers' purchase behaviour and references future research on related aspects. Consequently, this research investigates the following objectives:

RO1. Examine the relationship between social media marketing and customers' purchase intention of boutique hotels in Malaysia.

RO2. Investigate which social media marketing methods are most influential to the boutique hotel customers' purchase intention.

The remainder of this paper is structured as follows. The following section presents the literature review and hypothesis development along with the conceptual framework of the study. Sections "Research Methodology" and "Results" present the methodology applied and report the results and confirm this research hypothesis. Finally, the last section draws conclusions and outlines directions for further research.

\section{Literature Review and Hypotheses Development}

\subsection{The Concept of Boutique Hotel}

The emergence of boutique hotels is one of the most exciting improvements in the leisure hotel industry. Lim and Endean (2009) described boutique hotels as "a combination of highquality service, excellent facilities and location". Boutique hotels embody the local history and cultural characteristics and provide guests with authentic local culture or engaging historical experiences. The most competitive boutique hotels and branded hotel chains are boutique hotels' design components and uniqueness considering differentiation strategies (Ahmad, Hemdi, \& Othman, 2017). Malaysia has abundant heritage elements, such as historical buildings, historical sites, and unique local culture, which provide both developers and boutique operators with opportunities (As, Ahmad, \& Jamal, 2018). These boutique hotels are built 
according to boutique hotel operators' ideas, ensuring the hotel's unique concept and creating unforgettable guests. The design of boutique hotels and their exceptional cultural services provide consumers with a unique cultural experience that is not replaceable by any other product (Lee \& Chhabra, 2015; Ujang, Moulay, \& Zakaria, 2018).

\subsection{Social Media Marketing}

With the increasing popularity of social media marketing in academia, social media marketing has obtained various scholars' views (Vinerean, 2017). Some scholars describe social media marketing as the root of achieving business purposes because social media marketing is related to customer loyalty, willingness to purchase, and consumer rights (Felix, Rauschnabel, \& Hinsch, 2017; Yadav \& Rahman, 2017). Other scholars describe social media marketing as the tool to facilitate connection and interaction with existing and potential customers (Choi, Fowler, Goh, \& Yuan, 2016; Pham \& Gammoh, 2015; Tuten \& Solomon, 2017). Social media marketing is how enterprises produce, communicate, and achieve online marketing products or services through social media platforms and set up and preserve the relationships between stakeholders (Yadav \& Rahman, 2017). Social Media Marketing gains stakeholders' value by sharing information, promoting interaction, providing personalised buying suggestions, and forming word of mouth between stakeholders regarding existing and trending goods and services (Saura, 2020; Yadav \& Rahman, 2017). Social media marketing provides opportunities for both customers and marketers (Vinerean, 2017).

The current study implemented the Technology Acceptance Model (TAM) proposed by Venkatesh and Davis (1996). Davis (1986) first established and verified the TAM's primary hypothetical framework, explicitly intending to realise the consumer acceptance procedure in a better way. The model is mainly used to study the user and the system's recognition of the system after the interaction. The current literature on technology acceptance studies shows that TAM is a highly cited model that can predict usage, individual intentions, and individual users' acceptance of technology, and has gone through three stages of development: adoption, verification, and expansion (Samar, Ghani, \& Alnaser, 2017). TAM suggests that behavioural intention foresees technology utilisation, while attitude and perceived usefulness decide behaviour intention. Davis (1986) mentioned that although design features specifically impact perceived effectiveness and perceived ease of use, external variables influence the attitude or behaviour indirectly through the two variables. In TAM, usage portrays one's direct implementation of technology in their work setting.

In contrast, attitude depicts the degree of evaluative impact that an individual attaches to utilising such technologies in their work. Venkatesh and Davis (1996) provided the updated version of the Technology Acceptance Model after the main finding that perceived usefulness and perceived ease of use directly influence behaviour intention, thus eliminating the need for the attitude construct (Lai, 2017). The author used marketing activities, e-WOM, advertising, celebrity effect, and interaction as the current research's independent variables. Perceived usefulness and perceived trust were the mediating variables, and customer perceived intention was the dependent variable. Figure 1 depicts the research model used in this study. The definitions of the constructs and the theoretical basis explain the hypotheses in the following sections.

\subsection{Customer Purchase Intention}

Purchase intention is the transaction behaviour that the customer exhibits after evaluating the goods and services (Schiffman \& Kanuk, 2010). Morwitz (2014) specified that purchase intention is for assessing the effectiveness of marketing strategies to foretell sales and market share. Consumers' willingness to purchase will also be affected by the type of product reviewed (Lu, Chang, \& Chang, 2014). Word of mouth significantly affects consumers' purchase intentions (Tariq, Abbas, Abrar, \& Iqbal, 2017). Personal behaviour, attitudes, and unpredictable circumstances all impact purchase intentions (Kotler, 2003). Purchase intentions increase with an increase in promotional activities. Brand awareness and consumer familiarity with the brand will also directly affect consumers' purchase intention (Tariq et al., 2017). Brand awareness helps to create the brand's cognitive thinking and indirectly affects the customer's purchase intention in front of the brand image. The brand image plays an intermediary role in the relationship between brand awareness and the customer's purchase intention (Sharifi, 2014). Celebrity endorsements are more effective in increasing consumer brand awareness. The celebrity effect promotes product participation and brand loyalty and impacts consumer purchase.

\subsection{Marketing Activities}

Marketing activities are prevalent marketing methods around the world in recent years. It creates possibilities for new product promotion and brand representation and establishes brands. Marketing activities use various events as a carrier to enable companies to increase their brand value or increase sales. Social media works when marketing activities establish relationships between customers and companies. Social media marketing activities are an essential part of corporate brand formation. Social media's popularity, cost reduction, and competitors motivate marketers to carry out social media marketing activities. Social media marketing activities usually focus on customer satisfaction and the impact on customer behavioural intentions (Simon \& Tossan, 2018). Social media marketing activities are part of online marketing promotion strategies (Ismail, 2017), user ratings, reviews, recommendations, etc. (Hajli, 2015). These days, consumers follow their favourite brands on social media platforms such as Facebook and Twitter, keep themselves abreast with the latest products, and enjoy discounts and exclusive promotions (Hoffman \& Fodor, 2010; Seo \& Park, 2018). Marketing activities are for consumer participation, public awareness, product development and 
brand image. They can improve consumer reputation for the brand, thereby improving consumer loyalty, influencing consumers' purchasing intentions, and making shopping decisions to complete the actual purchasing behaviour. Hence the following hypotheses were formulated;

H1a: Marketing activities have a significant impact on consumers' perceived usefulness.

H1b: Marketing activities have a significant impact on consumers' perceived trust.

\subsection{Electronic Word-of-Mouth}

With the speedy development of the Internet and the expanding popularity of social media, Electronic Word-ofMouth (e-WOM) has become one of the most commonly used digital media for communication between consumers (Chu \& Kim, 2011). Electronic WOM is defined as any positive or negative comments made by past, present and future customers on the product or brand, provided to other consumers and organisations through social media platforms (Hennig-Thurau, Gwinner, Walsh, \& Gremler, 2004). Direct eWOM between customers can change their preferences and purchase behaviour (Tien, Rivas, \& Liao, 2019). Social media can offer a luxuriant foundation for e-WOM information, which can significantly impact consumer purchase decisions (Tien, Rivas, \& Liao, 2019). Compared with the situation where it was challenging to observe WOM in the past, marketers can better analyse and monitor consumer feedback through social media platforms and manage such information better. Simultaneously, though the business can obtain instant feedback from consumers through e-WOM, e-WOM itself has risks. The spread of some negative e-WOM will affect the brand's image (Kudeshia \& Kumar, 2017), so it is imperative to properly manage and encourage users to generate positive e-WOMs on social media platforms. The above discussion leads to the formulation of the following hypotheses.

H2a: Electronic word of mouth significantly impacts consumers' perceived usefulness.

H2b: Electronic word of mouth significantly impacts consumers' perceived trust.

\subsection{Advertising}

Organisations worldwide have begun to consider using various social media platforms to attract customers and establish profitable marketing relationships (Dwivedi, et al., 2017). These organisations spend a lot of time and capital using social media platforms to promote their products. One of the main goals of promotion is to shape the consumer's decision-making process. Compared with traditional mass media advertising or online advertising, social media advertising is more interactive with customers. It helps businesses achieve many marketing goals, such as improving customer awareness, building customer knowledge, shaping customer awareness, incentivising customer purchase behaviour, and promoting actual purchases
(Shareef, Mukerji, Dwivedi, Rana, \& Islam, 2019). As long as customers feel that social media advertising is related to their preferences and interests, they will be more inclined to purchase products advertised in social media advertising. Social media advertising should attract customers' attention cognitively and emotionally (Shareef et al., 2019). Many scholars have studied the issues related to social media platforms' promotion based on social media's strategic significance in advertising (Carrillat, d'Astous, \& Grégoire, 2014; Duffett, 2015). These scholars proposed that marketing advertisements on social media platforms can influence existing and potential customers' attitudes. The above discussion presents the following hypotheses.

H3a: Advertising significantly impacts consumers' perceived usefulness.

H3b: Advertising significantly impacts consumers' perceived trust.

\section{7 Celebrity effect}

Consumers' obsession with celebrities in the social networking environment can be attributed to the pursuit of fame and the rapid development of Web 2.0 (Jin, 2018). Marketers believe that celebrities can be attractive to consumers, and this positive trait can be transferred to recognised brands, so celebrity endorsement has been widely used in marketing (Chung \& Cho, 2017). The celebrity effect is equivalent to a brand effect, driving the crowd and encouraging spending (Jin, 2018). Celebrity endorsements come in many forms: direct recommendation, experience sharing, and simultaneous appearance of products in pictures or videos corresponding to explicit endorsements, implicit endorsements, and joint presentations (McCracken, 1989). Brand cooperation with influential online celebrities to promote their products has become a new trend called "impact marketing" (Veirman, Cauberghe, \& Hudders, 2017). Miller and Laczniak (2011) proposed in their research that the celebrity effect has a positive impact on brand awareness and brand loyalty. Many scholars have also suggested that the celebrity effect on advertising message attitudes (Silvera \& Austad, 2004), brand opinions (Till, Stanley, \& Priluck, 2008) and consumer buying intentions have a positive effect (Lafferty, Goldsmith, \& Newell, 2002). Based on the above literature, this study proposes the following hypotheses.

H4a: Celebrity effect has a significant impact on consumers' perceived usefulness.

H4b: Celebrity effect has a significant impact on consumers' perceived trust.

\subsection{Social Interaction}

Social media marketing is how companies create accounts on social media platforms to communicate with customers and provide online services to market their products. The various social networking websites and their interactive feature offer like-minded people a space to connect and develop business or 
social values across the Internet. Increasingly social websites (e.g., Facebook, WhatsApp, Instagram, etc.) are currently incorporating e-businesses into the profit model. Social media platforms allow users to create their pages, communicate and interact with their friends, and exchange information or share sources related to the brand Information (Matthee, 2011). Social media can significantly encourage customers to share content and views with companies and other customers (Yadav \& Rahman, 2017). Social media can promote interaction with other users through bulletin boards, chat rooms, or available websites, thereby effectively improving knowledge levels (Welch, et al., 2018). These interactions have fundamentally changed communication dynamics between brands and customers and promoted user-generated content in social media (Daugherty, Eastin, \& Bright, 2008). The interaction between enterprises and consumers and the interaction between consumers and the celebrities and friends they follow can impact consumers' purchase intentions through social media platforms. According to Stephen and Toubia (2010), most advantaged businesses are not generally those who use the social network but have access to more consumers. Based on the above discussion, the following hypothesis was proposed.

H5a: Interaction significantly impacts consumers' perceived usefulness.

H5b: Interaction significantly impacts consumers' perceived trust.

\section{9 Perceived Usefulness}

According to TAM, the customer's intention to adopt a particular technology depends on the perception of the technology's usefulness and ease of use. Perceived usefulness is defined as the extent to which persons believe that technology will enhance their productivity or job performance (Davis, Bagozzi, \& Warshaw, 1992). A significant body of TAM research has shown that perceived usefulness is a strong determinant of user acceptance, adoption, and usage behaviour (Davis, 1989; Taylor \& Todd, 1995). According to Davis (1989), perceived usefulness has a positive effect on behavioural intentions. Previous research in Malaysia found that a particular system's perceived usefulness directly and consequential impacts information systems (Ndubisi \& Jantan, 2003). Previous studies revealed that helpful information and convenience allow consumers' to complete transactions confidently and increase their willingness to buy (Chen \& Teng, 2013). Based on the content above, this study makes the following hypothesis:

H6: Perceived usefulness significantly impacts customer purchase intention.

\section{10 Perceived Trust}

Trust is a significant feature of social networks, and the degree of interpersonal trust can affect personal attitudes and the acceptance of information (Sullivan \& Kim, 2018). Trust is a crucial factor for the success of e-commerce, and it also has an important impact on customer loyalty (Safa \& von Solms, 2016). Trust is a critical determinant of consumer behaviour in the ecommerce environment, and it is also one of the essential prerequisites affecting purchase intention. Trust can reduce online consumers' concerns about the ambiguity of transactions and minimise the difficulty of interaction with sellers, thus facilitating transactions' efficiency (Shanmugam, Sun, Amidi, Khani, \& Khani, 2016). Generally, customers prefer the opinions of professional bodies and experts for more specialised products. As far as goods are concerned, customers are vulnerable to the impact of family, friends and online reviews. Whether they are experts, friends or online reviews, customers have different levels of trust in them. Likewise, if a customer has a high degree of confidence in social media platforms, they are more likely to purchase online (Sullivan \& Kim, 2018). It can be established that the sense of trust in social media has a significant effect on users' decision-making. Therefore, based on the above discussion, the following hypothesis was proposed.

H7: The level of perceived trust in social media significantly impacts customer purchase intention.

Figure 1 - Conceptual framework of the study

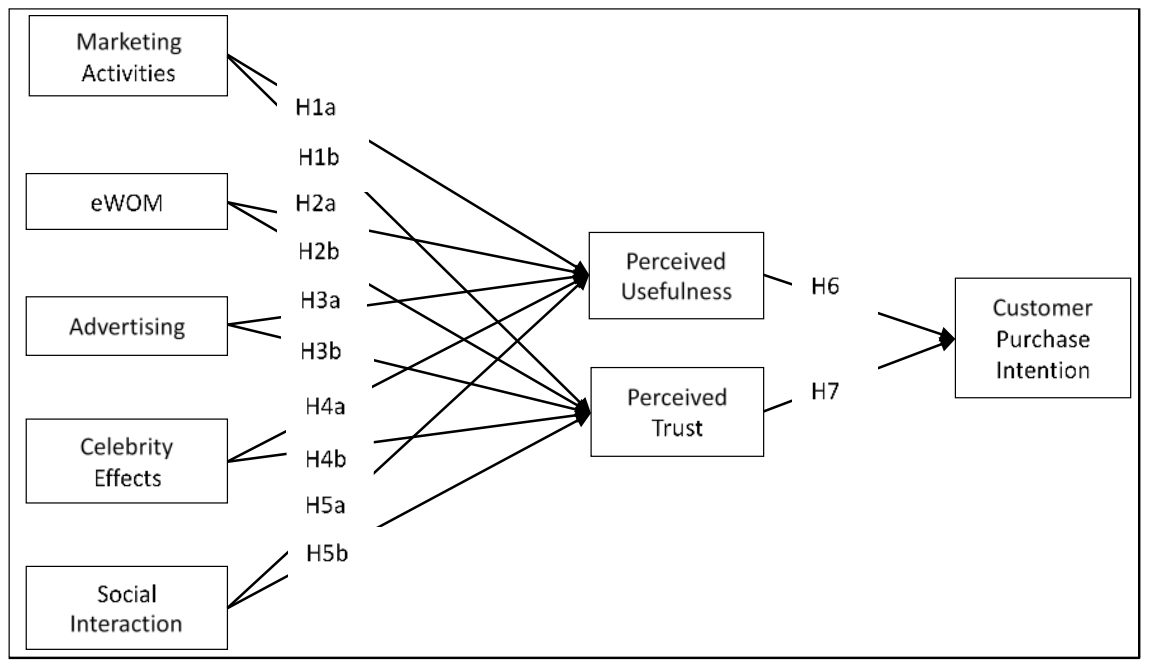




\section{Research Methodology}

\subsection{Research Design}

Research design is an outline for collecting, estimating, and investigating the data based on the study's research questions (Sekaran \& Bougie, 2015). A positivist paradigm approach drives the current study. The objective of conducting a positivist study is to investigate a social or human subject to explain the phenomenon (Zhang, 2009) comprehensively. The positivist paradigm is additionally mentioned as systematic, empiricist, quantitative or deductive. To achieve the research objectives and get the answers to this study's research hypotheses, a quantitative study approach must be the most appropriate methodology due to the specified purposes. A quantitative research design is suitable because it requires evaluating connections between variables using a quantitative research approach. This research adopted a deductive method to determine social media marketing's influencing factors on Malaysian boutique hotel customers' purchase intention and achieve the research objectives. A non-probability convenience sampling technique was used for data collection where samples were selected from the population only because they are conveniently available to the researcher.

\subsection{Instrument Development}

A questionnaire was designed with items adapted from a prior literature review. The questionnaire for the current study was organised into two sections. The first section included questions on the respondents' demographic characteristics, such as age, gender, education and profession. The second section contained questions on the significant constructs included in the research framework. The dimension scales of the questionnaire for all items in the second section was established on the 5-point Likert scale ranging from "strongly disagree" (1) to "strongly agree" (5)

Section two included a total of 27 items for independent variables such as Marketing Activities (4 items), e-WOM (4 items), Advertising (4 items), Celebrity Effects (3 items), Interaction (4 items) to evaluate two mediating variables including Perceived Usefulness ( 3 items) and Perceived Trust ( 3 items) and one dependent variable Purchase Intention (2 items). The items for the various constructs used in this study were adapted from the preceding studies (Alalwan, 2018; Cho \& Sagynov, 2015; Choi \& Yu, 2018; Chung \& Cho, 2017; Djurica \& Mendling, 2020; Erkan \& Evans, 2018; Fischer \& Reuber, 2011; Hutter, Hautz, Dennhardt, \& Füller, 2013; Jamal \& Sharifuddin, 2015; Kim \& Ko, 2012; Ladhari \& Michaud, 2015; Laksamana, 2018; Pappas, 2017; Racherla \& Friske, 2012; Yadav \& Rahman, 2017; Yen \& Teng, 2015). Accordingly, seven different hypotheses were derived from the above model.

\subsection{Data Collection and Analysis Techniques}

An online questionnaire was created, and data was collected through social media online platforms such as Facebook,
WhatsApp, Instagram and WeChat. According to the data provided by datareportal.com, as of January 2021, Malaysia's existing Internet users are 27.43 million, and there were 28 million social media users in Malaysia in January 2021 (Kemp, 2020). Data was collected from Malaysian social media users, and the sample comes from customers of boutique hotels among Malaysian social media users. For the current research, the author utilised SPSS version 25 to perform the data analysis. Descriptive analysis was carried out to analyse the demographic characteristics, and the instrument's reliability tests were carried out to ensure that all the constructs were free from random error. Correlation analysis and multiple regression analysis was performed to test the proposed hypothesised model.

\subsection{Demographic profile of the respondents}

A total of 309 respondents participated in this study. From the total collected valid sample size, $56 \%$ were male, and $44 \%$ were female. Most of the respondents were 26-32 years old, comprising $57 \%$ of respondents, followed by $18-25$ years old group with $29.1 \%$, whereas $10 \%$ were aged between 33 and 40 . These results depict that people aged between 26-32 years were the most popular group in responding, whereas people aged over 41 were less interested in the investigation. The findings also suggested that $44.7 \%$ of respondents had diploma level education, $36.6 \%$ had education up to foundation level, 12.3 were bachelor's degree graduates, and $6.5 \%$ were master's or PhD degree holders. The percentage of the profession of the respondents was closely distributed. The majority $(30.1 \%)$ of the respondents were students who were followed by the managers (18.1\%), academicians (14.6\%), professionals (13.9\%) and entrepreneurs (8.1. The remaining respondents were either government employees, retired people, or other professions not listed in the survey questionnaire.

\section{Results}

\subsection{Reliability of the study}

Cronbach's coefficient alpha has commonly used for the measurement of internal consistency reliability. According to (Kline, 2015), Cronbach's alpha value of 0.7 and above is reliable. Sekaran and Bougie (2019) believed that an alpha value of 0.5 is the lower acceptance value. Table 1 displays Cronbach's alpha coefficients for all constructs used in the study. All the measures exhibited adequate reliability with Cronbach's alpha values ranged between 0.690 and 0.889 , which falls within the recommended threshold of 0.70 (Pallant, 2005), which suggests that the "measures were free from random error and thus reliability coefficients estimate the amount of systematic variance" (Churchill, 1979). The overall Cronbach alpha value was also found to be 0.920 , extremely good. The higher Cronbach Alpha values showed that all the items were internally consistent, and the higher Cronbach Alpha for the overall scale specifies that convergent validity was met. 
Table 1 - Reliability Statistics

\begin{tabular}{|l|c|c|}
\hline Variables & Cronbach Alpha $(\boldsymbol{\alpha})$ & N of Items \\
\hline Marketing Activities & 0.856 & 4 \\
\hline Electronic Word-of-Mouth & 0.796 & 4 \\
\hline Advertisements & 0.750 & 4 \\
\hline Celebrity Effect & 0.706 & 3 \\
\hline Interaction & 0.690 & 4 \\
\hline Perceived Usefulness & 0.697 & 3 \\
\hline Perceived Trust & 0.889 & 3 \\
\hline Purchase Intention & 0.746 & 2 \\
\hline
\end{tabular}

\subsection{Correlation Analysis of the study variables}

In the current study, correlation analysis was employed because "correlation analysis includes measuring the closeness of the relationship between two or more variables; it considers the joint variation of two measures" (Churchill, 1995; Pallant, 2005). The correlation analysis was used for independent variables' Marketing Activities', 'e-WOM, 'Advertisement', 'Celebrity Effect', 'Interaction', 'Perceived Usefulness' and 'Perceived
Trust' towards the dependent variable 'Customer Purchase Intention' to test the correlation between them. In Table 2, the results of correlation analysis are significant at the 0.01 level. When the correlation coefficients matrix between study variables is examined, no correlation coefficient is equal to 0.90 or above. This examination supports this study's discriminant validity, which means that all the constructs are different/distinct (Amick \& Walberg, 1975) and indicates a strong positive correlation between the variables.

Table 2 - Correlation of the study

\begin{tabular}{|c|c|c|c|c|c|c|c|c|}
\hline Scales & 1 & 2 & 3 & 4 & 5 & 6 & 7 & 8 \\
\hline Marketing Activities & 1 & & & & & & & \\
\hline e-WOM & $.703^{* *}$ & 1 & & & & & & \\
\hline Advertisement & $.745^{* *}$ & $.781^{* *}$ & 1 & & & & & \\
\hline Celebrity Effect & $.408^{* *}$ & $.519^{* *}$ & $.749 * *$ & 1 & & & & \\
\hline Interaction & $.483^{* *}$ & $.547^{* *}$ & $.843^{* *}$ & $.848^{* *}$ & 1 & & & \\
\hline Perceived Usefulness & $.154^{* *}$ & $.286^{* *}$ & $.370^{* *}$ & $.410^{* *}$ & $.391 * *$ & 1 & & \\
\hline Purchase Intention & $.010 * *$ & $.058 * *$ & $.162^{* *}$ & $.228 * *$ & $.190 * *$ & $.562 * *$ & $.190 * *$ & 1 \\
\hline
\end{tabular}

**. Correlation is significant at the 0.01 level (2-tailed).

\subsection{Regression Analysis}

The authors performed a regression analysis to test multiple hypotheses implied in the study to understand consumers' perceived trust, usefulness, and purchase intention. One concern when performing regression is multicollinearity. Multi-collinearity is defined as the extent to which the other variables on the analysis can explain a variable. Multi-collinearity exists when two or more independent variables are "highly" correlated with one another (Zhang, 2009). A multicollinearity check was reached in the analysis by investigating the correlation matrix and the Variance Inflation Factor (VIF) values and tolerances. For standardised data, if the value of tolerance is less than 0.2 or 0.1 and simultaneously, the value of VIF 10 and above indicates harmful collinearity. The Durbin-Watson statistic is a test statistic used to detect autocorrelation in the residuals from a regression analysis. It has a range from 0 to 4 with a midpoint of 2 . It should be between 1.5 and 2.5 for independent observation (Zhang, 2009).
Table 3 reveals that regression analysis was applied to have 'Perceived Usefulness' as the dependent variable and 'Marketing Activities', 'Electronic word of mouth', 'Advertising', 'Celebrity Effect' and 'Interaction' independent variables. It was necessary to use the regression analysis to predict the implications of 'Perceived Usefulness. The obtained results exhibit that Marketing Activities $(\beta=0.564)$ and e-WOM ( $\beta=$ 0.502 ) exert a positive relationship with perceived usefulness, making $\mathrm{H} 1 \mathrm{a}$ and $\mathrm{H} 2 \mathrm{a}$ to be accepted. It was also found that Advertisement $(\beta=0.226)$, celebrity effect $(\beta=0.151)$ and interaction $(\beta=0.070$ ) does not have a positive relationship with perceived usefulness, making hypotheses $\mathrm{H} 3 \mathrm{a}, \mathrm{H} 4 \mathrm{a}$ and $\mathrm{H} 5 \mathrm{a}$ to be rejected. The results also showed that $R^{2}$ was 0.230 , and the $F$ value was 18.1 at a significance level $p<0.05$. The results displayed that the Durbin-Watson value was 2.220, and the variance inflations factor was below 3, signifying no multicollinearity problem.

Table 3 - Regression Analysis

\begin{tabular}{|l|c|c|c|c|c|l|}
\hline \multicolumn{7}{|c|}{ Mediating Variable: Perceived Usefulness } \\
\hline \multicolumn{1}{|c|}{ Independent Variables } & $\boldsymbol{\beta}$ & t- value & $\boldsymbol{p}$-value & Tolerance & VIF & \multicolumn{1}{|c|}{ Hypothesis } \\
\hline Marketing Activities & 0.564 & 4.457 & 0.000 & 0.159 & 6.298 & H1a - Significant \\
\hline e-WOM & 0.502 & 3.862 & 0.000 & 0.150 & 6.658 & H2a - Significant \\
\hline Advertisement & 0.226 & 1.613 & 0.108 & 0.129 & 7.739 & H3a - Not Significant \\
\hline Celebrity Effect & 0.151 & 1.522 & 0.129 & 0.259 & 3.859 & H4a - Not Significant \\
\hline Interaction & 0.070 & 0.53 & 0.574 & 0.166 & 6.032 & H5a - Not Significant \\
\hline
\end{tabular}


Second regression was analysed using 'Perceived Trust' as a dependent variable and 'Marketing Activities', 'Electronic word of mouth', 'Advertising', 'Celebrity Effect' and 'Interaction' as the independent variables. The results presented in Table 4 exhibit that Marketing Activities $(\beta=0.515)$ and e-WOM ( $\beta=$ 0.471) exerts a positive relationship with perceived trust, making $\mathrm{H} 1 \mathrm{~b}$ and $\mathrm{H} 2 \mathrm{~b}$ to be accepted. It was also found that Advertisement $(\beta=0.221)$, celebrity effect $(\beta=0.135)$ and interaction ( $\beta=0.118$ ) does not have a positive relationship with perceived usefulness, making hypotheses $\mathrm{H} 3 \mathrm{~b}, \mathrm{H} 4 \mathrm{~b}$, and $\mathrm{H} 5 \mathrm{~b}$ to be rejected. The results also showed that $R^{2}$ was 0.104 , and $F$ value was 51.3 at a significance level $p<0.05$. The results displayed that the Durbin-Watson value was 1.859 , and the variance inflations factor was below 3 , signifying no multicollinearity problem.

Table 4 - Regression Analysis

\begin{tabular}{|l|c|c|c|c|c|l|}
\hline \multicolumn{7}{|c|}{ Mediating Variable: Perceived Trust } \\
\hline \multicolumn{1}{|c|}{ Independent Variables } & $\boldsymbol{\beta}$ & $\mathbf{t}$ - value & $\boldsymbol{p}$-value & Tolerance & VIF & \multicolumn{1}{c|}{ Hypothesis } \\
\hline Marketing Activities & 0.515 & 3.774 & 0.000 & 0.159 & 6.298 & H1b - Significant \\
\hline e-WOM & 0.471 & 3.355 & 0.001 & 0.150 & 6.658 & H2b - Significant \\
\hline Advertisement & 0.221 & 1.461 & 0.145 & 0.129 & 7.739 & H3b - Not Significant \\
\hline Celebrity Effect & 0.135 & 1.260 & 0.209 & 0.259 & 3.859 & H4b - Not Significant \\
\hline Interaction & 0.118 & 0.884 & 0.377 & 0.166 & 6.032 & H5b - Not Significant \\
\hline
\end{tabular}

Notes: Durbin-Watson $=1.859, \mathrm{R}^{2}=0.104, \mathrm{~F}=51.3, \mathrm{p} \leq 0.05$

Third regression was analysed using 'Customer Purchase Intention' as a dependent variable while 'Perceived Usefulness' and 'Perceived Trust' were the independent variables. The results in table 5 indicate that perceived usefulness $(\beta=0.993)$, and perceived trust $(\beta=0.500)$ exerts a significant positive effect on customer purchase intention, making $\mathrm{H} 6$ and $\mathrm{H} 7$ to be found significant. The results also displayed that the Durbin-Watson value was 1.415 , and the variance inflations factor was also below 3 , thus showing no multicollinearity problem. $R^{2}$ was 0.429 and $F$ value at 115.024 at a significance level $p<0.05$.

Table 5 - Regression Analysis

\begin{tabular}{|l|c|c|c|c|c|c|}
\hline \multicolumn{7}{|c|}{ Dependent Variable: Purchase Intention } \\
\hline Mediating Variables & $\boldsymbol{\beta}$ & $\mathbf{t}$ - value & $\boldsymbol{p}$-value & Tolerance & VIF & Hypothesis \\
\hline Perceived Usefulness & 0.993 & 14.516 & 0.000 & 0.452 & 2.212 & H6-Significant \\
\hline Perceived Trust & 0.500 & 7.790 & 0.000 & 0.452 & 2.212 & H7 - Significant \\
\hline
\end{tabular}

Notes: Durbin-Watson $=1.415, R^{2}=0.429, F=115.024, p \leq 0.05$

\section{Discussion and Conclusion}

The rapid distribution of internet services has supported social media's rapid development. Many businesses have started using social media platforms for marketing, which has resulted in social media marketing strategies. In boutique hotels' social media marketing, different marketing methods have various performances, and these performances mainly affect consumers' final purchase intentions through consumer perception. Research has found that social media marketing methods will have different levels of response to consumers' perceived usefulness and perceived trust. The study's objectives were to examine the relationship between social media marketing and customers' purchase intention in Malaysia's boutique hotels. The study found that both the perceived usefulness and perceived trust significantly impacts customer purchase intention. In analysing social media marketing methods on perceived usefulness, the authors found that only marketing activities and e-WOM significantly impact perceived trust and are positively correlated. This finding is emphatically connected with previous authors' (Chen, 2012; Chen \& Teng, 2013; Davis, 1989). Further, results show that marketing activities and eWOM significantly impact the perceived trust. This finding is emphatically connected with previous authors' experiences (Chung \& Cho, 2017; Tien, Rivas, \& Liao, 2019).
According to the research findings, social media marketing affects consumer purchase intention in Malaysian boutique hotels through mediating variable perceived usefulness and perceived trust. Generally, consumers' perceptions will have a significant impact on their purchase intentions. Therefore, for boutique hotels, marketing professionals should effectively use social media marketing approaches. This research has filled the gaps in the study of Malaysian boutique hotel's customer purchase intention. Based on the research findings, this study puts forward various suggestions for developing social media marketing for boutique hotels, including different practical and theoretical implications.

Electronic WOM plays a significant role in shaping customers' perceptions. Many consumers share their experiences on social media networks. Consumers are not only the receivers of information but also disseminators of information. The formation of this intangible interaction between consumers will affect their purchasing intentions. The e-WOM can be presented in the form of text, pictures or videos. Texts, images, and videos can increase social media users understanding of boutique hotels and enhance their perceived usefulness. Therefore, the maintenance of e-WOM is essential for boutique hotels. Boutique hotel marketing professionals must check consumer feedback on social media platforms and address 
consumers' complaints, negative feedback, or suggestions professionally. This kind of e-WOM maintenance is called "web care" (van Noort \& Willemsen, 2012). Previous studies proved that "web care" can prevent negative results of e-WOM, prevent negative e-WOM from evolving into a corporate crisis, and reduce customer complaints (van Noort G., Willemsen, Kerkhof, \& Verhoeven, 2015). Regular "web care" is essential for the hotel's growth in the social media environment. Responsible public image and good electronic word-of-mouth can also enhance consumers' perceived trust and improve consumers' purchasing intentions.

The marketing activities also have a significant impact on perceived usefulness and perceived trust. Research on the impact of marketing activities on businesses is tremendous. Marketing activities allow companies to connect with customers (Hoffman \& Fodor, 2010; Kelly, Kerr, \& Drennan, 2010). Lee (2017) divided the company's social media activities into communication, information provision, promotion, social reactions, and daily life support. Marketing activities change the one-way information transmission mode between the company and customers into two-way direct communication. Although marketing activities have no significant impact on perceived usefulness and perceived trust in this study, the hotels cannot ignore their influence on consumers' purchase intention. Boutique hotels should continuously improve social media marketing content, keep up with the latest trends, and be innovative. Boutique hotels should spend more attention to the individualisation of content creation. Boutique hotels can design different themes for different marketing activities and always explore personalised ways to attract more customers and achieve better marketing responses.

Findings confirm that advertising, celebrity effects, and social interaction doesn't impact on perceived usefulness and perceived trust. Studies have shown that consumers' perceptions of online advertising are becoming increasingly hostile, and consumers perceive some formats as intrusive (Saura et al., 2021; Chatterjee, 2008; Truong \& Simmons, 2010). Perception of aggressiveness may be classified as adverse marketing outcomes associated with user anger and brand avoidance but may also increase the likelihood of leaving the online platform (Goodrich, Schiller, \& Galletta, 2015). Therefore, it is necessary to better understand consumers' views on advertising in various social media formats to help managers choose the most effective advertising form (Yin et al., 2019). Many studies have proved that users can easily share their views, ideas, and experiences with friends and peers on social media platforms. This kind of information sharing may affect other users' purchase decisions (Xiang et al., 2016; Wang $\& Y u, 2017)$. Boutique hotels should encourage consumers to share their hotel experiences on social media platforms to enhance their brand awareness through the right word of mouth and positive reviews. To improve social media marketing effectiveness, boutique hotels must reply to guests' posts on social media platforms on time, making consumers feel valued.

\section{Theoretical Contributions}

In the Web2.0 era, the fast spread of the Internet has enabled social media's rapid development. More and more businesses use social media platforms for marketing, which has resulted in social media marketing strategies. Based on this background, this study surveyed different social media marketing methods. This study analyses how different social media marketing methods affect Malaysian boutique hotel customers' purchase intentions through perception factors. It was found that both the perceived usefulness and perceived trust significantly impacted customer purchase intention. Three of the five social media marketing methods (electronic word of mouth, celebrity effect, and interaction) in this study significantly impact the perceived usefulness. Electronic word of mouth and celebrity effects have a significant impact on perceived trust. According to the findings, this study puts forward different development suggestions for different social media marketing methods. The research has filled the gaps in the research on Malaysian boutique hotels customer purchase intention.

\section{Managerial Contributions}

From a more practical point of view, managers and heads of marketing can use the results of the present study as the starting point to efficiently use social media marketing approaches. Social media is a valuable platform to receive complaints, feedback and suggestions from the hotel's customers. Hence boutique hotel marketing professionals should pay more attention to check consumer feedback on social media platforms and respond quickly to feedback received and address consumers' complaints, their negative feedback or suggestions in a professional way and assist customers promptly to increase the chances that customer will choose their hotel.

\section{Limitations and Future Research}

One of the most significant limitations of this research was not considering all the original and the first modified version of the TAM model. This research did not include the 'attitude' variable of the TAM model as it was excluded based on the findings of (Venkatesh \& Davis, 1996). Future research may consider the use of attitude variables and a more detailed analysis of various social media marketing techniques. Future research may also employ mixed-method techniques, which will enhance the research's reliability and generalizability. This research was limited to the use of the technology acceptance model. A similar study may be carried out in the future by employing the Unified Theory of Acceptance and Use of Technology (UTAUT) model, as this is the most recent model to study technology acceptance behaviour. Future research can also investigate customer participation in social media, post-purchase behaviour like repurchase intention and loyalty. This study can also help hospitality and tourism researchers to understand the online tourist purchase intention. The present research could be a reference when a company makes marketing strategic decisions to improve its online purchase intention. 


\section{References}

Abbas, J., Aman, J., Nurunnabi, M., \& Bano, S. (2019). The Impact of Social Media on Learning Behavior for Sustainable Education: Evidence of Students from Selected Universities in Pakistan. Sustainability, 11(6), 1683. doi:10.3390/su11061683

Aggett, M. (2007). What has influenced growth in the UK's boutique hotel sector? International Journal of Contemporary Hospitality Management, 19(2), 169-177.

Ahmad, N. F., Hemdi, M. A., \& Othman, D. N. (2017). Boutique hotel attributes and guest behavioral intentions. Journal of Tourism, Hospitality \& Culinary Arts, 9(2), 257-266.

Alalwan, A. A. (2018). Investigating the impact of social media advertising features on customer purchase intention. International Journal of Information Management, 42, 65-77.

Alhabash, S., \& Ma, M. (2017). A Tale of Four Platforms: Motivations and Uses of Facebook, Twitter, Instagram, and Snapchat Among College Students? Social media + Society, 1-13. doi:10.1177/2056305117691544

Amick, D. J., \& Walberg, H. J. (1975). Introductory Multivariate Analysis. California: McCutchan Publishing Corporation.

Arora, A., Bansal, S., Kandpal, C., Aswani, R., \& Dwivedi, Y. (2019). Measuring social media influencer index-insights from Facebook, Twitter and Instagram. Journal of Retailing and Consumer Services, 49, 86-101. doi:10.1016/j.jretconser.2019.03.012

As, A., Ahmad, A., \& Jamal, S. (2018). As, A., Ahmad, A., \& Jamal, S. (2018). Factors of Guest Experiential Value of Boutique Hotels in the City of Kuala Lumpur. Journal of Tourism and Hospitality, 7(2), 1-3. doi:10.4172/2167-0269.1000342

Baccarella, C. V., Wagner, T. F., Kietzmann, J. H., \& McCarthy, I. P. (2018). Social media? It's serious! Understanding the dark side of social media. European Management Journal, 36(4), 431-438. European Management Journal, 36(4), 431-438. doi:10.1016/j.emj.2018.07.002

Berezan, O., Krishen, A. S., Agarwal, S., \& Kachroo, P. (2018). The pursuit of virtual happiness: Exploring the social media experience across generations. Journal of Business Research, 89, 455-461. doi:10.1016/j.jbusres.2017.11.038

Bernama. (2017, September 26). Tourism sector to maintain position as 3rd largest contributor to economy. Retrieved from www.nst.com.my: https://www.nst.com.my/news/nation/2017/09/284233/tourismsector-maintain-position-3rd-largest-contributor-economy

Carrillat, A. F., d'Astous, A., \& Grégoire, M. E. (2014). Leveraging social media to enhance recruitment effectiveness A Facebook experiment. Internet Research, 24(4), 474-495. doi:10.1108/IntR-07-2013-0142

Chatterjee, P. (2008). Are unclicked ads wasted: enduring effects of banner and pop-up ad exposures on brand memory and attitudes. Journal of Electronic Commerce Research, 9, 51-61.

Chen, H. (2012). Hui Chen, The Influence of Perceived Value and Trust on Online Buying Intention. Journal of Computers, 7(7), 1655-1662.

Chen, M.-Y., \& Teng, C.-I. (2013). A comprehensive model of the effects of online store image on purchase intention in an e-commerce environment. Electronic Commerce Research, 13, 1-23. doi:10.1007/s10660-013-9104-5

Cho, Y. C., \& Sagynov, E. (2015). Exploring factors that affect usefulness, ease of use, trust, and purchase intention in the online environment. International Journal of Management \& Information Systems, 19(1), 21-36.

Choi, E.-K., Fowler, D., Goh, B., \& Yuan, J. (2016). Deborah Fowler, Ben Goh \& Jingxue (Jessica) Yuan Social Media Marketing: Applying the Uses and Gratifications Theory in the Hotel Industry. Journal of Hospitality Marketing \& Management, 25(7), 771-796. doi:10.1080/19368623

Choi, Y. S., \& Yu, S. (2018). The Effect of VR Advertisement Characteristic Components on the Perceived Usefulness and Easiness, and Advertisement Attitude. International Journal of Pure and Applied Mathematics, 120(6), 5371-5387.

Chu, S.-C., \& Kim, Y. (2011). Determinants of consumer engagement in electronic word-of-mouth (eWOM) in social networking sites.
International Journal of Advertising, 30(1), 47-75. doi:10.2501/IJA-30-1047-075

Chung, S., \& Cho, H. (2017). Fostering Parasocial Relationships with Celebrities on Social Media: Implications for Celebrity Endorsement. Psychology \& Marketing, 34(4), 481-495. doi:10.1002/mar.21001

Churchill, A. G. (1979). Marketing Research: Methodological Foundations. New York, NY: Dryden Press.

Churchill, A. G. (1995). Marketing Research: Methodological Foundations (6th ed.). New York: Dryden Press.

Daugherty, T., Eastin, M. S., \& Bright, L. (2008). Exploring Consumer Motivations for Creating User-Generated Content. Journal of Interactive Advertising, 8(2), 16-25. doi:10.1080/15252019.2008.10722139

Davis, F. D. (1986). A technology acceptance model for empirically testing new end-user information systems: Theory and results (Doctoral dissertation). Massachusetts Institute of Technology. Retrieved from http://hdl.handle.net/1721.1/15192

Davis, F. D. (1989). Perceived Usefulness, Perceived Ease of Use, and User Acceptance of Information Technology. MIS Quarterly, 13(3), 319-340.

Davis, F. D., Bagozzi, R. P., \& Warshaw, P. R. (1992). Extrinsic and intrinsic motivation to use computers in the workplace. Journal of Applied Psychology, 22(14), 1109-1130.

Djurica, D., \& Mendling, J. (2020). Impact of Influencer Type and Advertisement Disclosure on Perceived Trust, Credibility and Purchase Intention. AMCIS 2020 Proceedings, (p. 15). Salt Lake City, Utah.

Duffett, R. G. (2015). Facebook advertising's influence on intention-topurchase and purchase amongst Millennials. Internet Research, 25(4), 498-526. doi:10.1108/IntR-01-2014-0020

Duffett, R. G. (2017). Influence of social media marketing communications on young consumers' attitudes. Young Consumers, 18(1), 19-39. doi:10.1108/YC-07-2016-00622

Dwivedi, Y. K., Rana, N. P., Tajvidi, M., Lal, B., Sahu, G. P., \& Gupta, A. (2017). Exploring the Role of Social Media in e-Government: an Analysis of Emerging Literature. Proceedings of the 10th International Conference on Theory and Practice of Electronic Governance (pp. 97106). New York: Association for Computing Machinery.

Erkan, I., \& Evans, C. (2018). Social media or shopping websites? The influence of eWOM on consumers' online purchase intentions. Journal of Marketing Communications, 24(6), 617-632.

Felix, R., Rauschnabel, P. A., \& Hinsch, C. (2017). Elements of strategic social media marketing: A holistic framework. Journal of Business Research, 70, 118-126. doi:10.1016/j.jbusres.2016.05.001

Fischer, E., \& Reuber, A. R. (2011). Social interaction via new social media:(How) can interactions on Twitter affect effectual thinking and behavior?. Journal of Business Venturing, 26(1), 1-18.

Garg, A. (2020). Factors Influencing Generation $Y$ to Choose AIRBNB. In A. Hassan, \& A. Sharma, The Emerald Handbook of ICT in Tourism and Hospitality (pp. 45-65). West Yorkshire, England: Emerald Publishing Limited. doi:10.1108/978-1-83982-688-720201004

Goldfarb, A., McDevitt, R., Samila, S., \& Silverman, B. S. (2015). The Effect of Social Interaction on Economic Transactions: Evidence from Changes in Two Retail Formats. Management Science, 61(12), 29632981. doi: $10.1287 / \mathrm{mnsc} .2014 .2030$

Goodrich, K., Schiller, S. Z., \& Galletta, D. (2015). Consumer reactions to intrusiveness of online-video advertisements do length, informativeness, and humor help (or hinder) marketing outcomes? Journal of Advertising Research, 55(1), 37-50. doi:10.2501/jar-55-1-037-050

Hajli, N. (2015). Social commerce constructs and consumer's intention to buy. International Journal of Information Management, 35(2), 183191. doi:10.1016/j.ijinfomgt.2014.12.005

Hennig-Thurau, T., Gwinner, K. P., Walsh, G., \& Gremler, D. D. (2004). Electronic word-of-mouth via consumer-opinion platforms: What motivates consumers to articulate themselves on the Internet? Journal of Interactive Marketing, 18(1), 38-52. doi:10.1002/dir.10073 
Hinton, P. R., McMurray, I., \& Brownlow, C. (2014). SPSS Explained (2nd ed.). East Sussex: Routledge.

Hoffman, D. L., \& Fodor, M. (2010). Can you measure the ROI of your social media marketing?. MIT Sloan Management Review, 52(1), 41.

Hutter, K., Hautz, J., Dennhardt, S., \& Füller, J. (2013). The impact of user interactions in social media on brand awareness and purchase intention: the case of MINI on Facebook. Journal of Product \& Brand Management, 22(5/6), 342-351. https://doi.org/10.1108/JPBM-052013-0299

Internetworldstats. (2020, November 12). Internet Usage Statistics. Retrieved from Internetworldstats.com: https://www.internetworldstats.com/stats.htm

Ismail, A. R. (2017). The influence of perceived social media marketing activities on brand loyalty: The mediation effect of brand and value consciousness. Asia Pacific Journal of Marketing and Logistics, 29(1), 129-144. doi:10.1108/APJML-10-2015-0154

Jamal, A., \& Sharifuddin, J. (2015). Perceived value and perceived usefulness of halal labeling: The role of religion and culture. Journal of Business Research, 68(5), 933-941.

Jin, S. (2018). “Celebrity 2.0 and beyond!" Effects of Facebook profile sources on social networking advertising. Computers in Human Behavior, 79, 154-168. doi:10.1016/j.chb.2017.10.033

Kasasa. (2021, January 13). Boomers, Gen X, Gen Y, and Gen Z Explained. Retrieved from https://www.kasasa.com: https://www.kasasa.com/articles/generations/gen-x-gen-y-gen-z

Kelly, L., Kerr, G., \& Drennan, J. (2010). Avoidance of Advertising in Social Networking Sites: The Teenage Perspective. Journal of Interactive Advertising, 10(2), 16-27. doi:10.1080/15252019.2010.10722167

Kemp, S. (2020, February 18). Digital 2020 Malaysia. Retrieved from https://datareportal.com/: https://datareportal.com/reports/digital2020-malaysia

Kim, A. J., \& Ko, E. (2012). Do social media marketing activities enhance customer equity? An empirical study of luxury fashion brand. Journal of Business Research, 65(10), 1480-1486.

Kline, R. B. (2015). The mediation myth. Basic and Applied Social Psychology, 37, 202-213. doi:10.1080/01973533.2015.1049349

Kotler, P. (2003). Marketing Management (11th ed.). New Jersey: Prentice Hall Inc.

Kudeshia, C., \& Kumar, A. (2017). Social eWOM: does it affect the brand attitude and purchase intention of brands? Management Research Review, 40(3), 310-330. doi:10.1108/MRR-07-2015-0161

Ladhari, R., \& Michaud, M. (2015). eWOM effects on hotel booking intentions, attitudes, trust, and website perceptions. International Journal of Hospitality Management, 46, 36-45.

Lafferty, B. A., Goldsmith, R. E., \& Newell, S. J. (2002). The Dual Credibility Model: The Influence of Corporate and Endorser Credibility on Attitudes and Purchase Intentions. Journal of Marketing Theory and Practice, 10(3), 1-11. doi:10.1080/10696679.2002.11501916

Lai, P. C. (2017). The Literature Review of Technology Adoption Models and Theories for the Novelty Technology. Journal of Information Systems and Technology Management, 14(1), 21-38. doi:10.4301/S1807-17752017000100002

Laksamana, P. (2018). Impact of social media marketing on purchase intention and brand loyalty: Evidence from Indonesia's banking industry. International Review of Management and Marketing, 8(1), 13-18.

Lee, S. (2017). A study on different recognition of importance in enterprises' social media activities based on comparison between consumers and enterprise: Focusing on commercial and relational characteristics of activity types. South Korea: Masters Dissertation. Hankuk University of Foreign Studies.

Lee, W., \& Chhabra, D. (2015). Heritage hotels and historic lodging: Perspectives on experiential marketing and sustainable culture. Journal of Heritage Tourism, 10(2), 103-110. doi:10.1080/1743873X.2015.1051211
Lim, M. W., \& Endean, M. (2009). Elucidating the aesthetic and operational characteristics of UK boutique hotels. International Journal of Contemporary Hospitality Management, 21(1), 38-51. doi:10.1108/09596110910930179

Lu, L., Chang, W., \& Chang, H. (2014). Consumer attitudes toward blogger's sponsored recommendations and purchase intention: The effect of sponsorship type, product type, and brand awareness. Computers in Human Behavior, 34, 258-266. doi:10.1016/j.chb.2014.02.007

Matthee, C. (2011). Towards the two-way symmetrical communication model: the use of social media to create dialogue around brands. Port Elizabeth, South Africa: Doctoral Dissertation. Nelson Mandela Metropolitan University.

McCracken, G. (1989). Who Is the Celebrity Endorser? Cultural Foundations of the Endorsement Process. Journal of Consumer Research, 16(3), 310-321. doi:10.1086/209217

Miller, F. M., \& Laczniak, G. R. (2011). The Ethics of Celebrity-Athlete Endorsement: What Happens When a Star Steps Out of Bounds? Journal of Advertising Research, 51(3), 499-510. doi:10.2501/JAR-51-3-499-510 Morwitz, V. (2014). Consumers' Purchase Intentions and their Behavior. Foundations and Trends ${ }^{\circledR}$ in Marketing, 7(3), 181-230. doi:10.1561/1700000036

Ndubisi, N. O., \& Jantan, M. (2003). Evaluating IS usage in Malaysian small and medium-sized firms using the technology acceptance model. Logistics Information Management, 16(6), 440-450. doi:10.1108/09576050310503411

Olanrewaju, A. T., Hossain, M. A., Whiteside, N., \& Mercieca, P. (2020). Social media and entrepreneurship research: A literature review. International Journal of Information Management, 50(2), 90-110. doi:10.1016/j.ijinfomgt.2019.05.011

Pallant, J. (2005). SPSS survival manual. A step by step guide to data analysis using SPSS for Windows (version 12) (2nd ed.). New York: Open University Press.

Pappas, N. (2017). Effect of marketing activities, benefits, risks, confusion due to over-choice, price, quality and consumer trust on online tourism purchasing. Journal of Marketing Communications, 23(2), 195-218.

Payne, M. (2019, April 12). Expert's Voice: Importance of social media in hospitality. Retrieved from https://tophotel.news/: https://tophotel.news/experts-voice-importance-of-social-media-inhospitality/

Pham, P. H., \& Gammoh, B. S. (2015). Characteristics of social media marketing strategy and customer-based brand equity outcomes: a conceptual model. International Journal of Internet Marketing and Advertising, 9(4), 321-337. doi:10.1504/IJIMA.2015.072885

Pikas, B., \& Sorrentino, G. (2014). The effectiveness of online advertising: consumer's perceptions of ads on Facebook, Twitter and YouTube. Journal of Applied Business and Economics, 16(4), 70-81.

Racherla, P., \& Friske, W. (2012). Perceived 'usefulness' of online consumer reviews: An exploratory investigation across three services categories. Electronic Commerce Research and Applications, 11(6), 548-559.

Safa, N. S., \& von Solms, R. (2016). Customers repurchase intention formation in e-commerce. South African Journal of Information Management, 18(1), 1-9. doi:10.4102/sajim.v18i1.712

Samar, S., Ghani, M., \& Alnaser, F. (2017). Predicting customer's intentions to use internet banking: the role of technology acceptance model (TAM) in e-banking. Management Science Letters, 7(11), 513524. doi:10.5267/j.msl.2017.8.004

Saura, J.R. (2020). Using Data Sciences in Digital Marketing: Framework, Methods, and Performance Metrics, Journal of Innovation and Knowledge, 1(2020). doi: 10.1016/j.jik.2020.08.001

Saura, J. R., Ribeiro-Soriano, D., \& Palacios-Marqués, D. (2021). From user-generated data to data-driven innovation: A research agenda to understand user privacy in digital markets. International Journal of Information Management, 102331. 10.1016/j.ijinfomgt.2021.102331 
Schiffman, L. G., \& Kanuk, L. L. (2010). Consumer Behaviour (10th ed.). London: Pearson Prentice Hall.

Sekaran, U., \& Bougie, R. (2015). Research Methods for Business: A skillBuilding Approach. New Delhi: Wiley India Pvt. Ltd.

Sekaran, U., \& Bougie, R. (2019). Research Methods For Business: A Skill Building Approach (8th ed.). West Sussex, UK: John Wiley \& Sons.

Seo, E.-J., \& Park, J.-W. (2018). A study on the effects of social media marketing activities on brand equity and customer response in the airline industry. Journal of Air Transport Management, 66(C), 36-41. doi:10.1016/j.jairtraman.2017.09.014

Shanmugam, M., Sun, S., Amidi, A., Khani, F., \& Khani, F. (2016). The applications of social commerce constructs. International Journal of Information Management, 36, 425-432. doi:10.1016/j.ijinfomgt.2016.01.007

Shareef, M. A., Mukerji, B., Dwivedi, Y., Rana, N., \& Islam, R. (2019). Social media marketing: Comparative effect of advertisement sources. Journal of Retailing and Consumer Services, 46(C), 58-69. doi:10.1016/j.jretconser.2017.11.001

Sharifi, S. S. (2014). Impacts of the trilogy of emotion on future purchase intentions in products of high involvement under the mediating role of brand awareness. European Business Review, 26(1), 43-63. doi:10.1108/EBR-12-2012-0072

Shivakumar, S. M. (2018). Social media marketing and its influence on millennials' buying behaviour. BIMS International Research Journal of Management and Commerce, 3(1), 1-4.

Silvera, D. H., \& Austad, B. (2004). Factors predicting the effectiveness of celebrity endorsement advertisements. European Journal of Marketing, 38(11/12), 1509-1526. doi:10.1108/03090560410560218

Simon, F., \& Tossan, V. (2018). Does brand-consumer social sharing matter? A relational framework of customer engagement to brandhosted social media. Journal of Business Research, 85, 175-184. doi:10.1016/j.jbusres.2017.12.050

Stefanone, M. A., Lackaff, D., \& Rosen, D. (2010). The Relationship between Traditional Mass Media and "Social Media": Reality Television as a Model for Social Network Site Behavior. Journal of Broadcasting \& Electronic Media, 54(3), 508-525. doi:10.1080/08838151.2010.498851

Stephen, A. T., \& Toubia, O. (2010). Deriving value from social commerce networks. Journal of Marketing Research, 47(2), 215-228. doi:10.1509/jmkr.47.2.215

Sullivan, Y. W., \& Kim, D. J. (2018). Assessing the effects of consumers' product evaluations and trust on repurchase intention in e-commerce environments. International Journal of Information Management, 39, 199-219. doi:10.1016/j.ijinfomgt.2017.12.008

Taha, V. A., Pencarelli, T., Škerháková, V., Fedorko, R., Košíková, M. (2021). The Use of Social Media and Its Impact on Shopping Behavior of Slovak and Italian Consumers during COVID-19 Pandemic. Sustainability, 13, 1710. doi: 10.3390/su13041710

Tariq, M., Abbas, T., Abrar, M., \& Iqbal, A. (2017). EWOM and brand awareness impact on consumer purchase intention: mediating role of brand image. Pakistan Administrative Review, 1(1), 84-102.

Taylor, S., \& Todd, P. A. (1995b). Decomposition and crossover effects in the theory of planned behaviour: A study of consumer adoption intentions. International Journal of Research in Marketing, 12(2), 137155. doi:10.1016/0167-8116(94)00019-K

Tien, D. H., Rivas, A. A., \& Liao, Y. K. (2019). Examining the influence of customer-to-customer electronic word-of-mouth on purchase intention in social networking sites. Asia Pacific Management Review, 24(3), 238-249. doi:10.1016/j.apmrv.2018.06.003

Till, B. D., Stanley, S. M., \& Priluck, R. (2008). Classical conditioning and celebrity endorsers: An examination of belongingness and resistance to extinction. Psychology \& Marketing, 25(2), 179-196. doi:10.1002/mar.20205

Tran, G. A., \& Strutton, D. (2014). Has reality television come of age as a promotional platform? Modeling the endorsement effectiveness of celebreality and reality stars. Psychology \& Marketing, 31(4), 294-305. doi:10.1002/mar.20695
Truong, Y., \& Simmons, G. (2010). Perceived intrusiveness in digital advertising: strategic marketing implications. Journal of Strategic Marketing, 18(3), 239-256. doi:10.1080/09652540903511308

Tuten, T. L., \& Solomon, M. R. (2017). Social media marketing (3rd ed.). London, United Kingdom: SAGE Publications.

Ujang, N., Moulay, A., \& Zakaria, J. (2018). Visitors' Attachment to Historic Tourism Places in Kuala Lumpur City Centre towards Sustainable Urban Regeneration. Environment-Behaviour Proceedings Journal, 3(9), 165-172. doi:10.21834/e-bpj.v3i9

UK Essays. (2017, May 15). The Hospitality Industry Of Malaysia. Retrieved from www.ukessays.com: https://www.ukessays.com/essays/tourism/exploring-the-hospitalityindustry-of-malaysia-tourism-essay.php

van Noort, G., \& Willemsen, L. M. (2012). Online Damage Control: The Effects of Proactive Versus Reactive Webcare Interventions in Consumer-generated and Brand-generated Platforms. Journal of Interactive $\quad$ Marketing, 26(3), 131-140. doi:10.1016/j.intmar.2011.07.001

van Noort, G., Willemsen, L. M., Kerkhof, P., \& Verhoeven, J. M. (2015). Webcare as an Integrative Tool for Customer Care, Reputation Management, and Online Marketing: A Literature Review. In P. J. Kitchen, \& E. Uzunoğlu, Integrated Communications in the Postmodern Era. London: Palgrave Macmillan.

Varkaris, E., \& Neuhofer, B. (2017). The influence of social media on the consumers' hotel decision journey. Journal of Hospitality and Tourism Technology, 8(1), 101-118. doi:10.1108/JHTT-09-2016-0058

Veirman, M. D., Cauberghe, V., \& Hudders, L. (2017). Marketing through Instagram influencers: the impact of number of followers and product divergence on brand attitude, 36:5, DOI: International Journal of Advertising, 36(5), 798-828. doi:10.1080/02650487

Venkatesh, V., \& Davis, F. D. (1996). A model of the antecedents of perceived ease of use: Development and test. Decision Sciences, 27(3), 451-481.

Vinerean, S. (2017). Importance of strategic social media marketing. Expert Journal of marketing, 5(1), 28-35.

Wang, Y., \& Yu, C. (2017). Social interaction-based consumer decisionmaking model in social commerce: The role of word of mouth and observational learning. International Journal of information Management, 37(3), 179-189. doi:10.1016/j.ijinfomgt.2015.11.005

Welch, V., Petkovic, J., Simeon, R., Presseau, J., Gagnon, D., Hossain, A., DesMeules, M. (2018). Interactive social media interventions for health behaviour change, health outcomes, and health equity in the adult population. Cochrane Database of Systematic Reviews, 1-24. doi:10.1002/14651858.CD012932

Xiang, L., Zheng, X., Lee, M. K., \& Zhao, D. (2016). Exploring consumers' impulse buying behavior on social commerce platform: the role of parasocial interaction. International Journal of Information Management, 36(3), 333-347.

Yadav, M., \& Rahman, Z. (2017). Measuring consumer perception of social media marketing activities in e-commerce industry: Scale development \& validation. Telematics Informatics, 34(7), 1294-1307. doi:10.1016/j.tele.2017.06.001

Yen, C. H., \& Teng, H. Y. (2015). Celebrity involvement, perceived value, and behavioral intentions in popular media-induced tourism. Journal of Hospitality \& Tourism Research, 39(2), 225-244.

Yin, X., Wang, H., Xia, Q., \& Gu, Q. (2019). How social interaction affects purchase intention in social commerce: A cultural perspective. Sustainability, 11(8), 2423. doi:10.3390/su11082423

Zhang, K. Z., \& Benyoucef, M. (2016). Consumer behavior in social commerce: A literature review. Decision Support Systems, 86, 95-108. doi:10.1016/j.dss.2016.04.001

Zhang, W. (2009). The Motivations, Constraints and Decision-making of Beijing Outbound Tourists. PhD Thesis, University of Waikato. Hamilton: Department of Tourism and Hospitality Management. 